\title{
PKM Pada Kelompok Masyarakat Kelurahan Lahendong Kecamatan Tomohon Selatan Kota Tomohon Tentang Pemanfaatan Obat Tradisional Sebagai Terapi Komplementer Pada Penyakit Degeneratif
}

\author{
Widya Astuty Lolo ${ }^{1 *}$, Adithya Yudistira ${ }^{1}$, Olvie Syenni Datu ${ }^{1}$ \\ ${ }^{1}$ Program Studi Farmasi, Fakultas Matematika dan Ilmu Pengetahuan Alam, Universitas Sam Ratulangi \\ Manado, 95115, Sulawesi Utara, Indonesia \\ * Penulis korespondensi : Widya Astuty Lolo. Email : widyaastutylolo@unsrat.ac.id
}

\begin{abstract}
ABSTRAK
Obat tradisional merupakan obat-obatan yang diolah secara tradisional, dan digunakan secara turun-temurun berdasarkan adat-istiadat, kepercayaan dan kebiasaan masyarakat setempat. Keanekaragaman hayati yang melimpah di Indonesia berpengaruh pada budaya dan pola hidup dalam masyarakat dengan memanfaatkan berbagai tanaman sebagai obat termasuk dalam terapi penyakit degeneratif. Mitra pada kegiatan ini yaitu kelompok masyarakat Kelurahan Lahendong Kecamatan Tomohon Selatan Kota Tomohon Provinsi Sulawesi Utara. Prevalensi penyakit degeneratif pada mitra yang cukup tinggi antara lain penyakit jantung, diabetes mellitus, dislipidemia dan hipertensi. Mayoritas masyarakat yang menjalani terapi formal dengan obat kimia juga menggunakan terapi obat tradisional secara berdampingan. Masyarakat belum memahami dengan benar tentang pentingnya pengaturan penggunaan obat yang benar bila menggabungkan keduanya. Kegiatan ini bertujuan untuk memberikan pengetahuan yang memadai bagi mitra terkait pemanfaatan obat tradisional sebagai terapi komplementer pada penyakit degeneratif. Berhubungan dengan hal tersebut, terdapat beberapa metode pelaksanaan yang diterapkan selama kegiatan, antara lain ceramah yang berisi materi tentang penyakit degeneratif dan pengobatannya, serta pilihan terapi obat tradisional sebagai terapi komplementer yang dapat diintegrasikan dalam terapi yang dijalani. Selain itu dilakukan diskusi bersama dengan peserta yang merupakan pihak yang sedang menjalani kedua terapi untuk mengkaji masalah secara mendalam yang disertai dengan pembagian brosur terkait materi penyuluhan, serta memberikan pelatihan tentang pengolahan obat tradisional yang baik. Adapun jenis-jenis tanaman obat yang dijelaskan merupakan tanaman obat yang familiar bagi masyarakat setempat, yaitu kunyit, jambu biji, belimbing manis, daun salam, tapak dara, belimbing wuluh, sirsak, seledri, ketimun, kumis kucing, mengkudu, bawang putih, alpukat, kubis, kacang tanah, labu siam, dan sambiloto. Berdasarkan kegiatan yang telah dilaksanakan dapat disimpulkan bahwa terjadi peningkatan pengetahuan masyarakat tentang pemanfaatan obat tradisional sebagai terapi komplementer pada penyakit degeneratif.
\end{abstract}

Kata kunci: Penyakit Degeneratif, Obat Tradisional

\begin{abstract}
Traditional medicines are medicines that are traditionally processed and used from generation to generation based on the customs, beliefs and habits of the local community. The abundant biodiversity in Indonesia affects the culture and lifestyle in society by utilizing various plants as medicine, including in the therapy of degenerative diseases. Partners in this activity are the community groups of Lahendong Village, South Tomohon District, Tomohon City, North Sulawesi Province. The relatively high prevalence of degenerative diseases in partners includes heart disease, diabetes mellitus, dyslipidemia and hypertension. The majority of people who undergo formal therapy with chemical drugs also use traditional medicinal therapy side by side. People do not understand correctly about the importance of regulating drug use
\end{abstract}


properly when combining the two. This activity aims to provide adequate knowledge for partners regarding the use of traditional medicine as a complementary therapy in degenerative diseases. In connection with this, there are several implementation methods that are applied during the activity, including lectures containing material on degenerative diseases and their treatment, as well as options for traditional medicinal therapies as complementary therapies that can be integrated into the current therapy. In addition, discussions were held with participants who were the parties undergoing both therapies to study the problem in depth, accompanied by distributing brochures related to counseling materials, as well as providing training on good traditional medicine processing. The types of medicinal plants described are medicinal plants that are familiar to the local community, namely turmeric, guava, sweet starfruit, bay leaves, tapak dara, starfruit, soursop, celery, cucumber, cat's whiskers, noni, garlic, avocado. , cabbage, peanuts, chayote, and sambiloto. Based on the activities that have been carried out, it can be concluded that there has been an increase in public knowledge about the use of traditional medicine as a complementary therapy in degenerative diseases.

Keywords: Degenerative Diseases, Traditional Medicine

\section{PENDAHULUAN} Analisis Situasi

Pola penyakit di Indonesia telah bergeser pada terjadinya peningkatan prevalensi penyakit degeneratif. Penyakit ini banyak ditemukan pada masyarakat usia lanjut. Penyakit degeneratif adalah penyakit tidak menular yang berlangsung kronis karena kemunduran fungsi organ tubuh akibat proses penuaan (Handajani et al., 2010). Terdapat tiga jenis penyakit degeneratif yang paling banyak terjadi di Indonesia ialah penyakit jantung, hipertensi dan diabetes mellitus. Hal ini berbanding lurus dengan kenyataan yang ditemukan di lapangan tentang data prevalensi penyakit degeneratif yang diperoleh dari 50 orang responden. Hasil survey menunjukkan bahwa terdapat 18 orang $(36 \%)$ penderita penjakit jantung, 13 orang (26\%) hipertensi, 12 orang (24\%) diabetes mellitus, dan penyakit degeneratif lainnya sebanyak 7 orang (14\%).

Lokasi mitra dalam kegiatan ini terdapat di Kelurahan Lahendong Kecamatan Tomohon Selatan Kota Tomohon. Mayoritas masyarakat penderita penyakit degeneratif seperti yang telah disebutkan di atas, menggunakan obat kimia bersamaan dengan obat herbal dengan tidak mengetahui aturan pakainya secara benar. Edukasi kesehatan yang telah dilakukan pihakpihak terkait termasuk dinas kesehatan dan puskesmas belum menyentuh pada masalah yang dihadapi mitra. Hasil survey awal yang dilakukan menunjukkan bahwa tingkat kejadian penyakit degeneratif cukup tinggi, sehingga diperlukan edukasi yang baik tentang penyakit ini yang meliputi pemahaman tentang penyakitnya, serta berbagai upaya yang dilakukan untuk mendapatkan hasil terapi yang optimal.

Prevalensi penyakit degeneratif yang cukup tinggi pada mitra juga didukung oleh data Riset Kesehatan Dasar (RISKESDAS) 2007, 2013, dan 2018 yang mencatat bahwa jumlah penderita penyakit tidak menular (PTM) di Sulawesi Utara sangat tinggi. Disposisi genetik maupun faktor lingkungan diduga memberi pengaruh. Studi ini bertujuan untuk memahami kecenderungan jangka panjang, serta prevalensi, dan komorbiditas PTM utama di Tomohon.

Data Dinas Kesehatan kota Tomohon menunjukkan hipertensi, arthritis dan penyakit sendi, serta diabetes mellitus konsisten menjadi penyakit metabolik utama selama 9 tahun terakhir. Selain itu, Dinas Kesehatan juga mencatat hiperurisemia dan stroke sebagai penyakit tidak menular yang ada hampir di seluruh Puskesmas di Kota Tomohon kecuali puskesmas Rurukan dan Pangolombian. Kedua Rumah Sakit di Tomohon mencatat hipertensi dan diabetes mellitus sebagai penyakit metabolik utama pasien rawat inap maupun rawat jalan. Survei secara langsung menunjukkan hipertensi, gout arthritis, hiperkolesterolmia, hiperurisemia dan diabetes mellitus merupakan 5 penyakit metabolik terbanyak pada populasi tersebut.

Kegiatan ini menyasar lokasi dimana telah dilakukan survey bahwa masyarakat setempat benar-benar membutuhkan edukasi tentang kesehatan khususnya bagaimana cara mengintegrasikan terapi utama dan terapi 
komplementer dengan menggunakan obat tradisional. Sejauh ini masyarakat menggunakan obat tradisional sebagai terapi komplementer pada penyakit degeneratif hanya sebatas pada kebiasaan secara turun-temurun dan berdasarkan adat-istiadat. Dalam perkembangan ilmu pengetahuan dibidang kesehatan telah mulai disandingkan terapi obat menggunakan obat kimia/sintetik dengan obat tradisional. Mengubah kesadaran, pola pikir dan gaya hidup masyarakat memerlukan adanya sosialisasi yang baik. Menurut Katno (2009), beralihnya masyarakat kepada obat tradisional karena harga lebih murah, bahan lebih mudah didapatkan bila ditanam sendiri, dan umumnya satu tanaman memiliki efek farmakologi lebih dari satu sehingga bermanfaat untuk pengobatan penyakit degeneratif dan metabolik. Kegiatan ini bertujuan untuk meningkatkan pemahaman mitra secara menyeluruh tentang obat tradisional sebagai terapi komplementer dalam penerapan prinsip pengobatan penyakit degeneratif yang benar.

\section{Permasalahan Mitra}

Berdasarkan analisis situsi yang dilakukan, maka permasalahan utama pada mitra dapat diuraikan sebagai berikut.

1. Kelompok masyarakat Kelurahan Lahendong Kecamatan Tomohon Selatan Kota Tomohon belum sepenuhnya memahami tentang penyakit degeneratif.

2. Kelompok masyarakat Kelurahan Lahendong Kecamatan Tomohon Selatan Kota Tomohon belum memahami cara memanfaatkan obat tradisional sebagai terapi komplementer pada penyakit degeneratif.

3. Perlunya upaya dalam mengubah persepsi masyarakat dalam menjalani terapi pengobatan baik menggunakan obat kimia tunggal maupun dikombinasikan dengan obat tradisional.

\section{Tujuan dan Manfaat kegiatan}

Kegiatan ini bertujuan untuk meningkatkan pengetahuan mitra terkait pemanfaatan obat tradisional sebagai terapi komplementer pada penyakit degeneratif. Adapun manfaat dari kegiatan ini ialah mitra dapat memanfaatkan tanaman obat dilingkungan sekitar secara optimal dalam upaya memaksimalkan hasil terapi pada penyakit degeneratif.

\section{METODE PELAKSANAAN \\ Sasaran Kegiatan Pengabdian}

Mitra pada kegiatan ini yaitu kelompok masyarakat Kelurahan Lahendong Kecamatan Tomohon Selatan Kota Tomohon yang terdiri dari kelompok masyarakat Lingkungan VI dan VIII.

\section{Lokasi Kegiatan Pengabdian}

Kegiatan ini dilaksanakan di kantor Kelurahan Lahendong Kecamatan Tomohon Selatan Kota Tomohon.

\section{Metode yang Digunakan}

Kegiatan ini dilaksanakan dengan metode sebagai berikut.

1. Ceramah

Materi ceramah yang diberikan antara lain tentang penyakit degeneratif yang banyak dialami oleh masyarakat usia lanjut yang terdiri dari definisi, jenis-jenis, penyebab dan pilihan terapi yang paling tepat serta pemanfaatan obat tradisional sebagai terapi komplementer secara umum dan secara khusus pada penyakit degeneratif.

2. Diskusi

Sasaran metode diskusi ini yaitu peserta yang pernah atau sedang menjalani terapi penyakit degeneratif dengan memanfaatkan obat tradisional sebagai terapi komplementer. Tujuannya ialah menggali informasi secara mendalam tentang praktek pengobatan yang telah diterapkan, sehingga dapat diarahkan menjadi lebih tepat bila terdapat kekeliruan.

\section{Pembagian brosur}

Brosur yang dibagikan terbagi menjadi 2 jenis berdasarkan isi materi, yaitu brosur tentang semua informasi tentang penyakit degeneratif dan brosur tentang obat tradisional yang dapat digunakan sebagai terapi komplementer.

\section{Pelatihan}

Pelatihan yang diberikan pada mitra yaitu tentang pengenalan dan pengolahan obatobat tradisional, mulai dari preparasi bahan baku sampai proses penyimpanan, serta cara pengolahan menjadi obat tradisional yang siap dikonsumsi. 


\section{HASIL DAN PEMBAHASAN}

Kegiatan pengabdian ini dilaksanakan pada bulan Agustus 2020 di Kelurahan Lahendong dan telah dilaksanakan sesuai dengan rencana serta dapat berjalan dengan baik berkat dukungan dari berbagai pihak. Kehadiran mitra sesuai dengan yang diharapkan. Kegiatan ini dilaksanakan secara bertahap sesuai dengan metode pelaksanaan yang telah direncanakan.

Penyakit degeneratif merupakan penyakit kronik menahun yang banyak mempengaruhi kualitas hidup serta produktivitas seseorang. Penyakit-penyakit degeneratif tersebut antara lain penyakit kardiovaskuler (jantung dan pembuluh darah) termasuk hipertensi, diabetes mellitus dan kanker (Brunner \& Suddarth, 2002). Secara global WHO (World Health Organization) memperkirakan penyakit tidak menular menyebabkan sekitar $60 \%$ kematian dan $43 \%$ kesakitan di seluruh dunia. Perubahan pola struktur masyarakat dari agraris ke industri dan perubahan gaya hidup, sosial ekonomi masyarakat diduga sebagai suatu hal yang melatarbelakangi meningkatnya prevalensi penyakit tidak menular, sehingga angka kejadian penyakit tidak menular semakin bervariasi dalam transisi epidemiologi. Penyakit degeneratif termasuk dalam kategori penyakit tidak menular ini.

Materi ceramah yang disampaikan pada kegiatan ini dibagikan pada seluruh peserta sebagai bahan informasi terkait kagiatan yang dilakukan. Materi tersebut berisi tentang jenisjenis penyakit degeneratif secara umum, hasil pemeriksaan dalam rangka penegakkan diagnosis oleh dokter, gejala dan tanda, penyebab, serta terapi farmakologi dan nonfarmakologi dengan menitikberatkan pada pemanfaatan obat tradisional (Gambar 1).

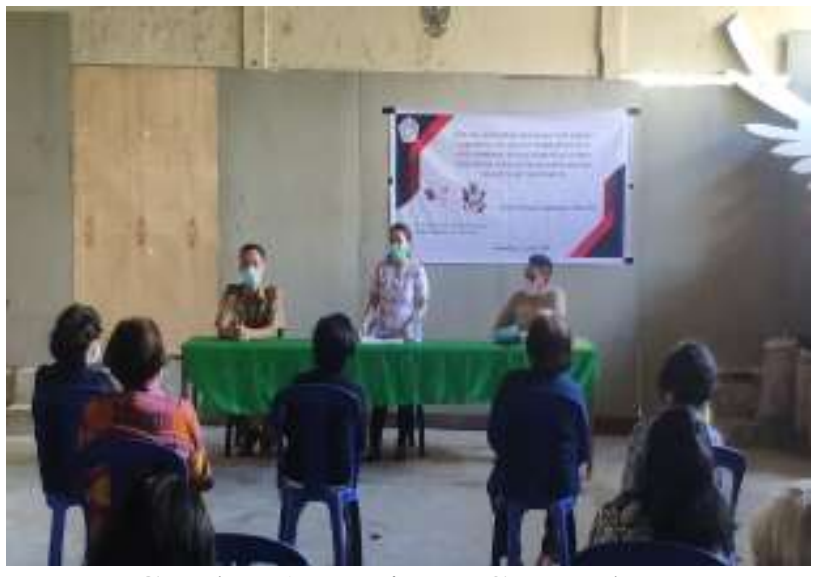

Gambar 1. Kegiatan Ceramah

Setelah memberikan penyuluhan tentang penyakit degeneratif dan pemanfaatan tanaman obat, selanjutnya dilakukan diskusi (Gambar 2) dengan tujuan untuk menggali masalah-masalah pokok yang sering terjadi pada mitra yang berhubungan dengan terapi penyakitnya. Beberapa permasalahan umum yang dijumpai diantaranya dalam menggunakan terapi obat tradisional, mitra tidak mengetahui bagian tanaman mana yang paling tepat digunakan, berapa takaran yang benar, serta bagaimana cara mengolahnya sehingga menjadi sediaan obat yang siap dikonsumsi. Hasil dari kegiatan diskusi ini yaitu masyarakat bertambah pengetahuannya tentang pemanfaatan obat tradisional yang benar.

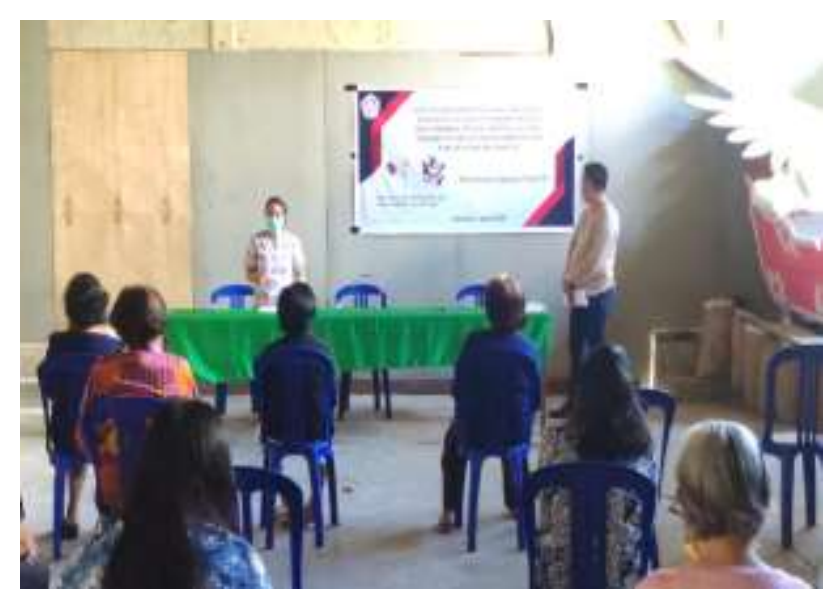

Gambar 2. Kegiatan Diskusi

Selama kegiatan diskusi berlangsung juga dilakukan pembagian brosur (Gambar 3) dengan tujuan peserta mendapatkan informasi tambahan yang dikemas dalam bentuk yang lebih 
menarik dengan harapan lebih mudah dipahami. Adapun isi brosur berfokus pada penyakit dan jenis tanaman obat serta pengolahannya yang dapat dimanfaatkan untuk penyakit tersebut.

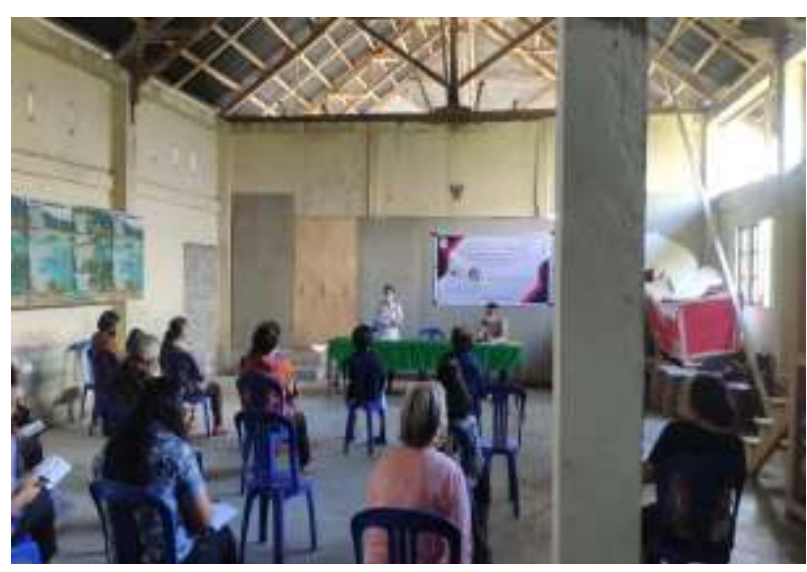

Gambar 3. Pembagian Brosur

Kegiatan selanjutnya yaitu mendemonstrasikan jenis-jenis tanaman obat serta cara pengolahannya menjadi sediaan obat yang siap untuk dikonsumsi. Beberapa diantaranya yaitu seledri, kunyit, jambu biji, belimbing manis, daun salam, tapak dara, belimbing wuluh, sirsak, ketimun, kumis kucing, mengkudu, bawang putih, alpukat, kubis, kacang tanah, labu siam, dan sambiloto. Berbagai tanaman ini merupakan tanaman yang cukup familiar bagi masyarakat, dengan harapan lebih memudahkan masyarakat dalam mengenal dan mengolahnya menjadi bahan obat. Pada bagian berikut ditunjukkan bagian tanaman seledri yang digunakan dan cara pengolahannya serta hasil yang diperoleh berupa hasil rebusan herba seledri yang siap dikonsumsi (Gambat 4).
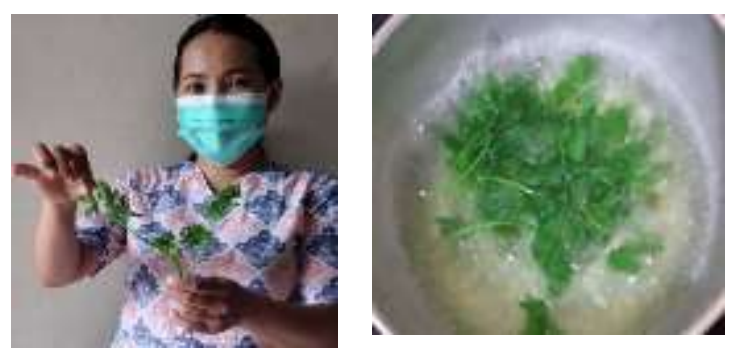

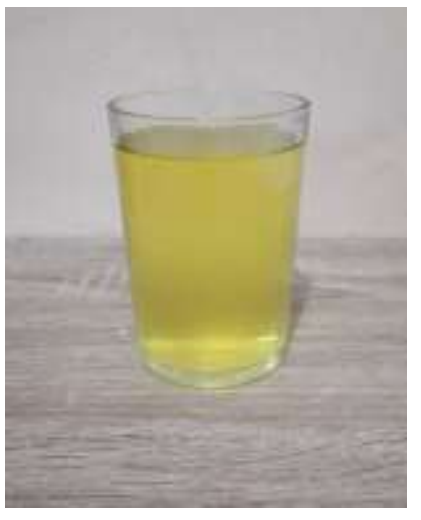

Gambar 4. Demonstrasi pengenalan dan pengolahan tanaman obat

Selama kegiatan berlangsung, antusiasme mitra dalam menerima materi bahkan pada saat diskusi cukup tinggi. Hal ini disebabkan karena sebagian besar dari mereka telah menggunakan obat tradisional secara bersamaan dengan obat kimia. Akan tetapi beberapa diantaranya masih kurang tepat dalam cara pengolahan obat tradisonalnya. Kegiatan ini dikatakan berhasil jika terjadi peningkatan pengetahuan dikalangan mitra tentang pengolahan obat tradisional yang baik. Oleh karena itu, pada bagian akhir kegiatan ini dilakukan post test mengenai jenis-jenis tanaman obat beserta cara pengolahannya menjadi ramuan obat tradisonal dengan cara pengolahan serta takaran yang tepat untuk dikonsumsi. Berdasarkan hasil post test tersebut, diketahui bahwa mitra dapat menjawab setiap pertanyaan dengan benar yang mengiindikasikan bahwa telah terjadi kenaikan tingkat pengetahuan mitra.

\section{KESIMPULAN DAN SARAN Kesimpulan}

Berdasarkan kegiatan yang telah dilakukan, dapat disimpulkan bahwa:

1. Terjadi peningkatan pengetahuan masyarakat tentang penyakit degeratif.

2. Pengetahuan masyarakat bertambah tentang berbagai tanaman obat serta cara pengolahannya yang dapat dimanfaatkan 
sebagai terapi komplementer pada penyakit degeneratif.

3. Masyarakat lebih memahami tentang cara menggunakan obat tradisional secara berdampingan dengan obat kimia.

\section{Saran}

Sosialisasi tentang pemanfaatan obat tradisional lebih ditingkatkan lagi untuk mendorong tercapainya derajat kesehatan yang optimal bagi masyarakat.

\section{UCAPAN TERIMA KASIH}

Terima kasih kepada Lembaga Penelitian dan Pengabdian Masyarakat Universitas Sam Ratulangi (LPPM- Unsrat) yang telah membiayai kegiatan Program Kemitraan Masyarakat tahun pendanaan 2020 ini. Terima kasih juga disampaikan kepada mitra kegiatan ini yaitu kelompok masyarakat Lingkungan VI dan VIII Kelurahan Lahendong, Kecamatan Tomohon Selatan, Kota Tomohon.

\section{DAFTAR PUSTAKA}

Ahmad, Jusda dkk. (2011). Kajian Etnobotani Tanaman Obat Oleh Masyarakat Kabupaten Bonebolango Provinsi Gorontalo. Laporan Penelitian Etnobotani Tanaman Obat. Jurusan Biologi FMIPA Universitas Negri Gorontalo: Online

Andrianto, T.T. (2011). Ampuhnya Terapi Herbal Berantas Berbagai Penyakit Berat. Najah. Yogyakarta.

Bangun, Abednego. (2012). Ensiklopedia Tanaman Obat Indonesia. Bandung. Indonesia Publising House. 2012. Jakarta.

Brunner \& Suddarth. (2002). Buku Ajar Keperawatan Medikal Bedah. Jakarta: EGC.

Dalimarta S., 2000, Atlas Tumbuhan Obat Indonesia.Cetakan I. PT. Pustaka Pembangunan Swadaya Nusantara. Jakarta

Handajani, A., Roosihermatie, B,. Maryani, H. 2010. Faktor-Faktor yang Berhubungan dengan Pola Kematian Pada Penyakit
Degeneratif di Indonesia. Buletin Penelitian Sistem Kesehatan. Vol. 13. No. 1. Jakarta: Badan Litbangkes Kemenkes RI. Anonim. 2009. UndangUndang Republik Indonesia No.36 tentang Kesehatan, Departemen Kesehatan RI, Jakarta

Indartiyah, Ndarie., et al. (2012). Direktorat Budidaya dan Pascapanen Sayuran dan Tanaman Obat. Direktoral Jenderal Holtikultural. Kementerian Pertanian RI. Jakarta.

Katno, P.S. 2009. Tingkat Manfaat dan Keamanan Tanaman Obat dan Obat Tradisional. Balai Penelititan Obat Tawangmangu. Fakultas Farmasi Universitas Gajah Mada. Yogyakarta: Fakultas Farmasi UGM.

Nursiyah. (2013). Studi Deskriptif Tanaman Obat Tradisional Yang Digunakan Orangtua Untuk Kesehatan Anak Usia Dini di Gugus Melati Kecamatan Kalikajar Kabupaten Wonosobo. Semarang: UNNES.

Permatasari, M.J. 2019. Studi Epidemiologi Penyakit Metabolik di Kota Tomohon. UGM Public Health Symposium. 